\title{
Cognition, Emotions, and Language in Front-Line Healthcare Workers: Clinical and Ethical Implications for Assessment Measures*
}

\section{Когніції, емоції та мовлення медпрацівників у стресових ситуаціях: клінічні та етичні імплікації для дослідницьких методів}

\author{
Larysa Zasiekina ${ }^{1}$ \\ Dr. Sc. in Psychology, \\ Professor
}

\author{
Лариса Засскіна ${ }^{1}$ \\ доктор психологічних наук, \\ професор
}

E-mail: zasyekina.larisa@vnu.edu.ua http://orcid.org/0000-0001-8456-0774

Scopus Author ID: 57215414977

ResearcherID: X-7055-2018

Tetiana Pastryk ${ }^{2}$

Ph.D. in Psychology
Тетяна Пастрик ${ }^{2}$

кандидат психологічних наук

E-mail: tetiana_pastryk@vmi.volyn.ua

https://orcid.org/0000-0002-6329-9607

Mariia Kozihora ${ }^{1}$

Post-Graduate Student in Psychology
Марія Козігора ${ }^{1}$

аспірантка в галузі психології

\section{E-mail: kozihora.mariia@vnu.edu.ua https://orcid.org/0000-0001-9597-952X}

* The project "Psychosocial Support for Healthcare Staff During COVID-19 Pandemic" was funded by the British Council in Ukraine, Agreement G129/20-19. The study was conducted from April till November, 2019.

** Проект “Психосоціальна підтримка медичного персоналу під час пандемії COVID-19” за фінансової підтримки Британської ради в Україні, G129/20-19. Дослідження проводилося з квітня по листопад 2019 року. 
Cognition, Emotions, and Language in Front-Line Healthcare...

Tetiana Fedotova ${ }^{1}$

Ph.D. in Psychology,

Associate Professor
Тетяна Федотова ${ }^{1}$

кандидат психологічних наук, доцент

E-mail: fedotova.tetiana@vnu.edu.ua

https://orcid.org/0000-0003-1975-9925

Serhii Zasiekin ${ }^{1}$

Dr.Sc. in Linguistics, Professor

\section{Сергій Засєкін}

доктор філологічних наук, професор

E-mail: sergiozasyekin@vnu.edu.ua

https://orcid.org/0000-0001-9453-3534

Scopus Author ID: 35112194200

ResearcherID: C-3094-2016
${ }^{1}$ Lesya Ukrainka Volyn National
University (Ukraine)
13 Volya Avenue, Lutsk,
Volyn region, 43025
${ }^{2}$ Volyn Medical Institute (Ukraine)
2 Lesi Ukrainky Str., Lutsk,
Ukraine, 43025

\author{
${ }^{1}$ Волинський наиіональний \\ університет імені Лесі Українки \\ (Украӥна) \\ $\triangle$ пр. Волі 13, м. Луцьк, \\ Волинська обл., 43025 \\ ${ }^{2}$ КЗВО “Волинський медичний \\ інститут" (Украӥна) \\ вул. Лесі Українки, 2, м. Луцьк, \\ Україна, 43025
}

Original manuscript received December, 12, 2020

Revised manuscript accepted September, 07, 2021

\begin{abstract}
Objectives. The article aims to reveal language-based markers of stressful experiences in healthcare workers in terms of their cognitions and emotions. The following research questions were formulated for the current study: (1) Are risk and protective factors for psychological stress in healthcare staff, working with patients with COVID-19 aligned with anxiety, depression and resilience? (2) Are there any language-based indicators for emotional distress in healthcare staff, working with patients with COVID-19? (3) What are the key cognitions, emotions, and behavioral patterns are expressed in healthcare workers' staff language? (4) What are words-associations in the Ukrainian Associative Dictionary aligned with language-based indicators of professional ethics in healthcare staff?

Materials and Methods. The study applies Beck's Depression Inventory (BDI-II), Beck's Anxiety Inventory (BAI), the Brief Resilient Coping Scale (BRCS), the Psychological Stress Scale (PSM-25), and the Linguistic Inquiry and Word Count (LIWC 2015).
\end{abstract}


Results. Results show that healthcare staff demonstrates a low level of psychological stress, depression and anxiety, and a medium level of resilience. The results of multiple linear regression indicate that the only significant negative predictor of stress is resilience. The psycholinguistic analysis of healthcare staff's narrative on their professional experience treating COVID-19 patients shows the key meaningful categories, namely social contacts, cognitive processes, and time. Social contacts are primarily represented by the category family. The word-associations from the Ukrainian Associative Dictionary indicate that feeling of guilt related to professional ethics in healthcare staff is more expressed in men compared with women.

Conclusion. The insights gained from this study may be of assistance to developing effective interventions for healthcare staff during a pandemic, primarily focusing on protective factors and weakening feelings of guilt to prevent moral injury. The study also raises some issues of the clinical psycholinguistic approach to examining emotional distress. This approach would be a fruitful area for further work.

Key words: clinical psycholinguistics, linguistic markers, words-associations, psychological stress, ethics, depression, anxiety, resilience, healthcare staff, LIWC.

\section{Introduction}

Analyzing speech during emotional distress is a direct and objective measure, highlighting the important processes in the human mind and mental health. Speech markers can provide a more direct assessment of the cognition and emotions of vulnerable groups in various stress situations. This fact amplifies the significance of the psycholinguistic approach to examining mental states in the situation of the pandemic.

Despite the implementation of WHO policy for protecting health during epidemics, the main focus has been made on preparations for an epidemic in terms of having national plans, epidemiological surveillance, vaccine and drug requirements, improved vaccination coverage among high-risk groups, as well as the economic impact and burden (Leigh et al., 2018). The world situation with coronavirus pandemic demonstrated that psychological and social aspects were mostly absent from national programs, however, were highly required.

The situation with corona-virus indicated that the most vulnerable population in terms of emotional distress, which requires psychological support is, the healthcare workforce, notably hospital staff and ambulance workers, giving the first aid to the patients with coronavirus. The issues of emotional exhaustion and stress in healthcare workers have 
been receiving considerable critical attention in the recent literature. Findings point out that healthcare staff, on the one hand, plays a critical role in the maintenance and spread of SARS-CoV-2, but, on the other hand, they are one of the most vulnerable groups for the poor impact of COVID-19.

Recent studies compare healthcare staff's contacts with SARS-CoV-2 and prior viruses SARS and Ebola (Bai et al., 2004; Shah et al., 2020). The hospital staff more likely reported exhaustion, detachment from others, anxiety when dealing with febrile patients, irritability, insomnia, poor concentration and indecisiveness, deteriorating work performance, and reluctance to work. Evidence of multinational studies constantly suggests that there are similar and different aspects in occupational health and safety risks during COVID-19 in various countries (Schiff et al., 2021). Emotional exhaustion, the shortage of equipment, and lack of diagnosis, specific treatment, anxiety aligned with exposure to high risk in relatives and colleagues, too many patients have a poor impact on the emergency health team's mental health and produce the continuous feeling of inevitable stress all over the world. However, healthcare workers emotional distress in Ukraine appears to be closely linked with working extra hours without appropriate equipment, effective governmental and social support, overwhelmed compassion and empathy towards patients with COVID-19. Coronavirus pandemic has a similar poor effect on healthcare teams' mental health, worsening the situation by the high mortality in population in general and in medical practitioners in particular.

Considering working healthcare staff's extra hours during the pandemic and poor access to assessing their mental conditions, researchers have not developed an efficient program for psychological support for healthcare staff during the pandemic. In addition, structural interviews, which are often applied in the studies, depending on subjective interpretation of researchers and participants, cultural bias, stigmas, and memory distortions (Marmar et al., 2019). Personal narratives often are fragmented or overwhelmed with emotions, which is explained by a poor impact of negative life events (Bifulco, 2021). Objective measures for assessing emotional distress often require much time and miss important individual information of the participants. Therefore, language is the most appropriate tool for revealing mental states naturally, saving researcher's and patients' efforts. 
Evidence consistently suggest that there is a growing interest in language and speech-based markers of mental disorders, namely substance used and panic disorders, PTSD, and with different target groups, particularly veterans, individuals with health conditions, students (Bedi et al., 2014; Krantz \& Pennebaker, 2007; Zhang et al., 2018). These studies explored the key features of individuals' speech and language, primarily language units, language meaningful categories, prosodic, voice quality, spectral, and glottal features for automated speech (van den Broek et al., 2010).

Despite the importance of mental health issues in healthcare staff, there remains a paucity of evidence on their cognitions and emotions, expressed in language. The study of language-based markers of stressful experience will explore the specifics of thoughts and feelings aligned with the pandemic in healthcare staff and outline the main trajectory of psychological support for this vulnerable group.

The article aims to reveal language-based markers of stressful experiences in healthcare workers in terms of their cognitions and emotions.

The literature on healthcare workers during pandemic has highlighted several issues, the key of them are connected with a lack of evidence on interventions for vulnerable groups, healthcare staff in particular (Uphoff et al., 2021). The findings of this research show that personal factors, the work environment, and social networks for mental health are the key risk- and protective factors in healthcare staff.

Carbajal et al. (2021) point out the poor psychosocial working conditions for this professional group, primarily physical and psychological abuse and discrimination by patients, which lead to poor outcomes in their mental health, namely anxiety, depression and acute stress.

Walton et al. (2020) indicate a strong association between stress and decision-making while treating patients with COVID-19. The most difficult decisions are related to the necessity of invasive treatment as urgent life-support for patients. This clinical decision is also connected with moral injury since the healthcare staff's forced behavior sometimes contravene the moral standards. The key negative feature of interaction between patients and healthcare staff during COVID-19 is complicated communication, related to the limited time of the face-to-face meeting.

Considering different mental conditions in healthcare staff as a response to the disaster, Walton et al. (2020) suggest classifying 
emotional distress into four types: not upset at all (some distress but recover with the support of family members, friends, or others); proportionately distressed, but able to function in the short and medium-term (not mentally disordered); disproportionately distressed or distressed and dysfunctional in the short to medium term (may recover relatively quickly if given appropriate assistance as well as those who may developmental disorders; therefore, people in this group require a thorough assessment); mentally disordered in the short, medium or longer-term (require specialist assessment followed by timely and effective mental healthcare) (p. 242).

Taking into consideration the limited access to complete healthcare workers' assessment Walton et al. (2020) suggest observable indicators of emotional distress, based on physical reactions (palpation, abdominal and chest pains, headaches, insomnia, hyperarousal, nausea, low appetite); behavioral (avoidance, recklessness, detachment, substance use, conflicts, withdrawal, irritability); emotional (numbness, low mood, anger, fear, mood swings, anhedonia, low confidence); cognitive (poor concentration, intrusive thoughts, flashbacks, poor memory, confusion, hypervigilance, rumination).

Together these studies provide important insights into the emotional distress of healthcare staff under working conditions during the pandemic, and the risk and protective factors for mental health impact in this professional group. However, considering the limited access to complex assessment and intervention programs due to the lack of time, express measures, primarily language-based indicators for mental health assessment are becoming vital.

As a response, the following research questions were formulated for the current study:

R1: Are risk and protective factors for psychological stress in healthcare staff, working with patients with COVID-19 aligned with anxiety, depression and resilience?

R2: Are there any language-based indicators for emotional distress in healthcare staff, working with patients with COVID-19?

R3: What are the key cognitions, emotions, and behavioral patterns are expressed in healthcare workers' staff language?

R4: What are words-associations in the Ukrainian Associative Dictionary aligned with language-based indicators of professional ethics in healthcare staff? 


\section{Adherence to Ethical Standards}

Before conducting the current study, ethical approval was obtained from the Ethics Committee of Lesya Ukrainka Volyn National University (No. 21, April, 2019). The approval letter to recruit the participants through Volyn Clinical Hospital was obtained from Volyn Oblast Department of Healthcare.

\section{Methods and Techniques of the Research}

\section{Participants}

To consider the heterogeneity of healthcare staff population, working with COVID-19 patients the study applies a maximum variation sampling strategy, regarding age, gender, marital status, occupational status, duration of the professional experience. After participants were provided with the participant information sheet and have consented, they were asked to complete the questionnaires. All participants were provided a link to Google forms to complete the questionnaires independently in a place of their convenience.

The results of the descriptive statistic of the sample are in Table 1.

Table 1

Descriptive information for the healthcare staff $(n=50)$

\begin{tabular}{ll}
\hline & Quantity, (\%) \\
\hline Total & $50(100 \%)$ \\
Men & $17(34.0 \%)$ \\
Women & $33(66.0 \%)$ \\
Experience in treating patients with COVID-19 & $50(100 \%)$ \\
Doctors & $30(60.0 \%)$ \\
Nurses & $20(40.0 \%)$ \\
Professional experience up to 5 years & $15(30.0 \%)$ \\
Professional experience up to 15 years & $14(28.0 \%)$ \\
Professional experience up to 25 years & $12(24.0 \%)$ \\
Professional experience of more than 25 years & $9(18.0 \%)$ \\
& Mean (SD) \\
Age & $44,05(0.60)$ \\
& Max 70.00 \\
\hline
\end{tabular}

14 (C) Засєкіна Л., Пастрик Т., Козігора М., Федотова Т. \& Засєкін С. 
Cognition, Emotions, and Language in Front-Line Healthcare...

\section{Measures}

Considering emotional distress as mental suffering and emotional response to a negative life event or conditions, primarily anxiety, depression and somatization, (Matsumoto, 2009), depression, anxiety, and psychological stress as risk factors and resilience as a protective factor were chosen as dependent variables.

(1). Beck's Depression Inventory (BDI-II). The Beck Depression Inventory-II (BDI-II) is one of the most widespread scales for assessing depression in adult participants. The Cronbach's alpha total score is 0.89 . It is positively correlated with the Hamilton Depression Rating Scale, $r=0.71$, which had a one-week test-retest reliability of $r=0.93$ (Beck et al., 1988b). The BDI-II is scored by summing the ratings for the 21 items. Each item is rated on a 4-point scale ranging from 0 to 3 . The maximum total score is 63 . Scores from 0 through 9 indicate no or minimal depression; scores from 10 through 18 indicate mild to moderate depression; scores from 19 through 29 indicate moderate to severe depression.

(2). Beck's Anxiety Inventory (BAI) demonstrates high internal consistency, the Cronbach's alpha is 0.92 ; test-retest reliability with a one week $=0.75$ and validity: the scale is moderately correlated with the revised Hamilton Anxiety Rating Scale (.51) and mildly correlated with the Hamilton Depression Rating Scale (.25). The total score is calculated by finding the sum of the 21 items, where a score of 0-21 low anxiety; a score of 22-35 - moderate anxiety; a score of 36 and above - potentially concerning levels of anxiety (Beck et al., 1988a).

(3). The Brief Resilient Coping Scale (BRCS), a 4-item measure designed to capture tendencies to cope with stress in a highly adaptive manner (Sinclair \& Wallston, 2004). RCS scores are additive from 4 to 20 , with higher scores denoting better resilience. Score range includes low resilient copers 4-13 points; medium resilient copers 14-16 points; high resilient copers 17-20 points. The BRCS shows medium internal consistency. The Cronbach's alpha total score is 0.59 .

(4). The Psychological Stress Scale (PSM-25), Cronbach's $\alpha$ lpha $=$ 0.74 , was used. The scale is unifactorial in structure and maintains test-retest stability of .68 to .80 under apparently constant conditions (Lemyre \& Tessier, 2004). The total score is calculated by finding the sum of the 25 items, where a score of 0-99 - low level of stress; 
a score of 100-154 - moderate level of stress; a score of 155 and above - high-stress level.

(5). The Linguistic Inquiry and Word Count (Pennebaker et al., 2015) was used for the analysis of healthcare staff's narratives containing their cognitions and emotions about their experience working with COVID-19 patients. Tausczik and Pennebaker (2010) pointed out that "The words we use in daily life reflect who we are and the social relationships we are in" (p. 25). The Ukrainian Applicable to the present study, we assume that psychological meaningful categories defined by LIWC might be language-based indicators of emotional distress in healthcare workers. The LIWC analyzes the words and administers them according to the pre-defined categories, linked to positive and negative emotions, motivation, thinking styles, and social relationships. In total, the LIWC defines the frequency of words for 125 categories based approximately on 6,400 words.

\section{Results}

The research dataset has been uploaded to Mendeley Data Repository (Zasiekin, 2021).

According to RQ1 anxiety, depression, stress, and resilience might be risk and protective factors for healthcare staff, working with COVID-19 patients. The descriptive statistics of all variables are indicated in Table 2.

Table 2

Means and standard deviations for all subjects $(n=50)$

\begin{tabular}{lllll}
\hline & Mean & $\begin{array}{l}\text { Standard } \\
\text { deviation }\end{array}$ & Minimum & Maximum \\
\hline Stress & 82.20 & 27.13 & 32.00 & 136.00 \\
Depression & 3.82 & 3.56 & .00 & 20.00 \\
Anxiety & 11.54 & 9.32 & .00 & 42.00 \\
Resilience & 14.40 & 2.48 & 8.00 & 19.00 \\
\hline
\end{tabular}

What is interesting about the data in this table is that healthcare staff demonstrated a low level of psychological stress. One possible explanation for this is protective factors, one of them is a medium level of resilience as an effective coping strategy in healthcare staff. 
These results are also in line with low levels of depression and anxiety. A closer inspection of the table shows that healthcare workers have no or minimal depression. This finding is contrary to previous studies which have suggested that levels of anxiety and depression are high among healthcare workers during the COVID-19 pandemic (Sahebi et al., 2021). The results of their study showed that the overall prevalence of anxiety and depression in medical staff during the COVID-19 pandemic was $24.94 \%(95 \%$ CI: $21.83-28.05, \mathrm{I} 2=0.0 \%, \mathrm{P}=0.804)$ and $24.83 \%(95 \%$ CI: $21.41-28.25, \mathrm{I} 2=0.0 \%, \mathrm{P}=0.897)$, respectively. These differences can be explained in part by various working conditions in countries and specifics of national healthcare systems. This is an important issue for future research of risk and protective factors of healthcare staff from a multinational perspective.

RQ1 was tested by multiple linear regression (see Table 3).

\section{Table 3}

Summary of Multiple Regression Analysis for Variables Predicting Stress ( $n=50)$

\begin{tabular}{lllll}
\hline Variables & B & SE B & $\boldsymbol{\beta}$ & t \\
\hline Depression & 1,61 & 0,96 & 0,21 & 1,67 \\
Anxiety & 1,81 & 0,36 & 0,62 & $4,97 * *$ \\
Resilience & $-0,68$ & 1,03 & 0,06 & 0,66 \\
\hline
\end{tabular}

Note: ${ }^{*} \mathrm{p}<.05,{ }^{* *} \mathrm{p}<.01$

What stands out in the table is that anxiety is the only significant independent negative predictor of stress. The relatively low indices of anxiety in the participants of our study also corroborate with low levels of stress. One possible explanation is that factors, associated with psychological distress in healthcare staff in recent studies, are being male, married, aged 40 years and older, and having more clinical experience of nursing (Alnazly et al., 2021). The sample in our study is mostly represented by doctors aged 44;05 years with clinical experience of up to 5 years. Therefore, the short clinical experience and occupational status of doctors might reduce the negative impact of risk factors.

The findings of our research were unexpected, therefore, deep psycholinguistic analysis was needed. The results of narrative analysis by software program LIWC were illustrated in Table 4. 
Когніції, емоції та мовлення медпрацівників у стресових...

\section{Table 4}

Language-based indicators of healthcare staff's emotional distress

\begin{tabular}{ll}
\hline Psychological meaningful categories & $\mathbf{\%}$ \\
\hline Negative emotions & 1.44 \\
Social contacts & 4.17 \\
Affects & 2.41 \\
Cognitive processes & 7.22 \\
Drives & 2.66 \\
Work & 2.57 \\
Focus on present & 1.61 \\
Health & 1.12 \\
Time & 3.53 \\
Family & 1.93 \\
\hline
\end{tabular}

As can be seen from the table above, the most frequent psychological categories are cognitive processes, social contacts, and time. These findings corroborate with Tausczik and Pennebaker's (2010) study, in which cognitive processes, time and focus on the present are associated with effective coping strategies to process negative life experiences, complete autobiographical memory, and avoid PTSD after a traumatic event. Cognitive words indicate appropriate cognitive processing of traumatic experiences by individuals, revealing all possible causes and consequences, and interpreting the event from an objective perspective. It may be also that these participants benefitted from social contacts, strengthening their resilience to cope with anxiety, depression, and stress. This explanation is in line with studies indicating that social support is essential for maintaining physical and psychological health (Ozbay et al., 2007). Social support is mostly represented by social interactions with other individuals, groups, and the larger community. As Table 4 indicates family is also key social tie for healthcare staff in our study.

Considering healthcare workers are held to a higher standard of morals and ethics than the general public, we assumed that they could experience moral injury. Moral injury, on the contrary to PTSD, is not defined as an anxiety disorder and relates to disintegrating meaning considering morality, notably moral standards, moral reasoning, moral behavior, and moral emotions (Zasiekina et al., 2020). The scholars indicate that the main predictor of developing PTSD in potentially 
morally injurious events is constructing the meaning of the event, which expresses the dissonance between moral standards and real behavior, resulting in moral emotions of shame and guilt, disgust, anger, and embarrassment.

The results of concept-based searching in healthcare staff's narratives show that the most frequent moral emotion in our sample is guilt. Participants in the healthcare staff sample share how their professional experience was especially difficult, which resulted in feelings of guilt.

(1) "We are involved in a stressful situation every hour and every day. The most stressful situation is to meet patients with low oxygen saturation and decided urgent intubation. Great stress is also aligned with vacant places in the hospital. When you understand that urgent intubation is needed and there is no place, I am feeling guilty toward the patient, his/her relatives, and myself".

(2) "It is very difficult to accept that you cannot control the situation, and you cannot help significant others. I blame myself for belonging to healthcare staff working with COVID-19 patients when I am helpless".

(3) "I have recurrent memories of the sudden death of our college. I felt guilt and helplessness in that situation. There was nothing we could do, but I cannot accept it. We are the hostages of this virus".

According to RQ4, we tested the words-associations of guilty feelings, represented in the Ukrainian Associative Dictionary separately for females and males in our sample (Martinek \& Mitkov, 2021). The associations, which were produced not less than three times, have been chosen (see Table 5).

\section{Table 5}

Words-associations for the concept of guilt represented in the Ukrainian associative dictionary

\begin{tabular}{ll}
\hline Words-associations in males (frequency) & Words-associations in females (frequency) \\
\hline $\begin{array}{l}\text { Mine (11), to lose (7), excuse (4), hard (3), } \\
\text { sorrow (3), to cope (3) }\end{array}$ & yours (18), excuse (5), large (3), confession (3), \\
\hline
\end{tabular}


Interestingly, different words-associations were observed in female and male samples indicated in the Ukrainian associative dictionary. The results show that men have a deeper feeling of guilt combining it with the adjective hard, noun sorrow, and verb to lose. Women apply word association of possessive pronouns mine and yours, which might express sharing the responsibility with somebody else. This result is somewhat counterintuitive and leads us to the assumption that women cope with the feeling of guilt more successfully comparatively with men. This result is in line with previous findings that the factor of being male is associated with psychological distress in healthcare staff (Alnazly et al., 2021).

Together these results provide important insights into languagebased indicators of cognitions and emotions, related to healthcare staff's emotional distress due to their experience of treating COVID-19 patients. These results also suggest that the low levels of stress, anxiety, and depression are associated with effective resilience in healthcare staff in Ukraine, based on deep social contacts, primarily on the family. Our findings indicate the feeling of guilt in the participants, which is aligned with decision making in urgent professional situations, does not lead to emotional distress in healthcare workers. One possible explanation for it might be developed resilience in healthcare workers.

\section{Conclusion}

This study set out to reveal language-based markers of stressful experience in healthcare workers in terms of their cognitions and emotions. One of the more significant findings to emerge from this study is that healthcare staff, having the experience to work with COVID-19 patients, demonstrate low levels of stress, anxiety, and depression, and a medium level of resilience. These data suggest that resilience can be achieved not only through appropriate work conditions but also through social support, which has a positive impact on healthcare staff's mental health.

The principal theoretical implication of this study is that the clinical psycholinguistic approach towards exploring healthcare staff's narratives can lead to a deep insight into their negative cognitions and emotions, resulting in emotional distress. These findings have also 
significant implications for the understanding of how language-based markers and words-associations indicate different levels of anxiety, depression, stress, and resilience. The insights gained from this study may be of assistance to developing effective interventions for healthcare staff during the pandemic, primarily focusing on protective factors and weakening feelings of guilt to prevent moral injury.

The major limitation of this study is the relatively small sample, however, applying maximum variation sampling strategy partially substantiates risk factors for emotional distress in healthcare staff in Ukraine. The study also raises some issues of the clinical psycholinguistic approach to examining emotional distress. This approach would be a fruitful area for further work.

\section{Acknowledgements}

The project "Psychosocial Support for Healthcare Staff During COVID-19 Pandemic" was funded by the British Council in Ukraine, Agreement G129/20-19. The study was conducted from April till November, 2019.

\section{References}

Alnazly, E., Khraisat, O.M., Al-Bashaireh, A.M., \& Bryant, C.L. (2021). Anxiety, depression, stress, fear, and social support during COVID-19 pandemic among Jordanian healthcare workers. Plos One, 16(3), Article e0247679. https://doi. org/10.1371/journal.pone.0247679

Bai, Y., Lin, C.C., Lin, C.Y., Chen, J.Y., Chue, C.M., \& Chou, P. (2004). Survey of stress reactions among health care workers involved with the SARS outbreak. Psychiatric Services, 55(9), 1055-1057. https://doi.org/10.1176/appi. ps.55.9.1055

Shah, K., Kamrai, D., Mekala, H., Mann, B., Desai, K., \& Patel, R.S. (2020). Focus on mental health during the coronavirus (COVID-19) pandemic: applying learnings from the past outbreaks. Cureus, 12(3), Article e7405. http://doi. org/10.7759/cureus.7405

Beck, A.T., Epstein, N., Brown, G., \& Steer, R.A. (1988a). An inventory for measuring clinical anxiety: psychometric properties. Journal of Consulting and Clinical Psychology, 56(6), 893. https://psycnet.apa.org/doi/10.1037/0022-006X.56.6.893

Beck, A.T., Steer, R.A., \& Garbin, G.M. (1988b). Psychometric properties of the Beck Depression Inventory: Twenty-five years of evaluation. Clinical Psychology Review, 8, 77-100. https://dx.doi.org/10.1186\%2F1753-2000-1-8

Bedi, G., Cecchi, G.A., Slezak, D.F., Carrillo, F., Sigman, M., \& De Wit, H. (2014). A window into the intoxicated mind? Speech as an index of psychoactive drug 
Когніції, емоції та мовлення медпрацівників у стресових...

effects. Neuropsychopharmacology, 39(10), 2340-2348. https://psycnet.apa.org/ doi/10.1038/npp.2014.80

Bifulco, A. (2021). Childhood trauma in women and fragmented interview narratives - some interdisciplinary methodological and clinical implications. East European Journal of Psycholinguistics, 8(1), 12-27. https://doi.org/10.29038/ eejpl.2021.8.1.bif

Carbajal, A.B., Boluarte, A.S., Boluarte, A.R., \& Soto, C.M. (2020). Working conditions and emotional impact in healthcare workers during COVID-19 pandemic. Journal of Healthcare Quality Research, 35(6), 401. https://doi. org/10.1016/j.jhqr.2020.08.002

Krantz, A.M., \& Pennebaker, J.W. (2007). Expressive dance, writing, trauma, and health: When words have a body. In I.A. Serlin, J. Sonke-Henderson, R. Brandman, \& J. Graham-Pole (Eds.), Whole person healthcare (Vol. 3: The arts and health), (pp. 201-229). Praeger Publishers.

Leigh, J., Fitzgerald, G., Garcia, E., \& Moon, S. (2018). Global epidemics: how well can we cope? British Medical Journal, 8, Article 362:k3254. https://doi. org/10.1136/bmj.k3254

Lemyre, L., \& Tessier, R. (2003). Measuring psychological stress. Concept, model, and measurement instrument in primary care research. Canadian Family Physician, 49, 1159-1168.

Marmar, C.R., Brown, A.D., Qian, M., Laska, E., Siegel, C., Li, M., ... \& Vergyri, D. (2019). Speech-based markers for posttraumatic stress disorder in US veterans. Depression and Anxiety, 36(7), 607-616. https://doi.org/10.1002/da.22890

Martinek, S., \& Mitkov, S. (2021). Ukrainskyi asotsiatyvnyi slovnyk [The Ukrainian Associative Dictionary]. (Vol. 3). Lviv: PAIS.

Matsumoto, D.E. (2009). The Cambridge dictionary of psychology. Cambridge University Press.

Ozbay, F., Johnson, D.C., Dimoulas, E., Morgan III, C.A., Charney, D., \& Southwick, S. (2007). Social support and resilience to stress: from neurobiology to clinical practice. Psychiatry (Edgmont), 4(5), 35-40.

Pennebaker, J.W., Boyd, R.L., Jordan, K., \& Blackburn, K. (2015). The development and psychometric properties of LIWC2015. Austin, TX: University of Texas at Austin.

Sahebi, A., Nejati, B., Moayedi, S., Yousefi, K., Torres, M., \& Golitaleb, M. (2021). The prevalence of anxiety and depression among healthcare workers during the COVID-19 pandemic: An umbrella review of meta-analyses. Progress in Neuro-Psychopharmacology and Biological Psychiatry, 110247. https://dx.doi. org/10.1016\%2Fj.pnpbp.2021.110247

Schiff, M., Zasiekina, L., Pat-Horenczyk, R., \& Benbenishty, R. (2021). COVIDrelated functional difficulties and concerns among university students during COVID-19 pandemic: A binational perspective. Journal of Community Health, 46(4), 667-675. https://dx.doi.org/10.1007\%2Fs10900-020-00930-9

Sinclair, V.G., \& Wallston, K.A. (2004). The development and psychometric evaluation of the Brief Resilient Coping Scale. Assessment, 11(1), 94-101.

Tausczik, Y.R., \& Pennebaker, J.W. (2010). The psychological meaning of words: LIWC and computerized text analysis methods. Journal of Language and Social Psychology, 29(1), 24-54. https://psycnet.apa.org/doi/10.1177/0261927X09351676

Uphoff, E.P., Lombardo, C., Johnston, G., Weeks, L., Rodgers, M., Dawson, S., ... \& Churchill, R. (2021). Mental health among healthcare workers and other 
vulnerable groups during the COVID-19 pandemic and other coronavirus outbreaks: A rapid systematic review. PloS One, 16(8), Article e0254821. https:// doi.org/10.1371/journal.pone.0254821

van den Broek, E.L., van der Sluis, F., \& Dijkstra, T. (2011). Telling the story and re-living the past: How speech analysis can reveal emotions in post-traumatic stress disorder (PTSD) patients. In J. Westerink, M. Krans, \& M. Ouwerkerk (Eds.), Sensing Emotions: The impact of context on experience measurements (pp. 153-180). (Philips Research Book Series; Vol. 12). Springer. https://doi. org/10.1007/978-90-481-3258-4_10

Walton, M., Murray, E., \& Christian, M.D. (2020). Mental health care for medical staff and affiliated healthcare workers during the COVID-19 pandemic. European Heart Journal: Acute Cardiovascular Care, 9(3), 241-247. https://doi. org/10.1177/2048872620922795

Zasiekin, Serhii (2021). Cognition, Emotions, and Language in Front-Line Healthcare Workers: Clinical and Ethical Implications. Mendeley Data, V1, https://doi. org/10.17632/xcy46g2wvr.1 or https://data.mendeley.com/datasets/xcy46g2wvr/1

Zasiekina, L., Hordovskya, T., \& Kozihora, M. (2020). Understanding Language and Speech in the Voice of Collective Trauma. In: L.O. Kalmykova, N.V. Kharchenko, \& I.V. Mysan (Eds.), Proceedings of the XV International Scientific and Practical Conference "Psycholinguistics in a Modern World 2020” (Pereiaslav-Khmelnytskyi, 22-23 October, 2020). (Vol. 15, pp. 84-88). https://doi.org/10.31470/10.31470/2706-7904-2020-15-84-88

Zhang, J., Pan, Z., Gui, C., Xue, T., Lin, Y., Zhu, J., \& Cui, D. (2018). Analysis on speech signal features of manic patients. Journal of Psychiatric Research, 98, 59-63. https://doi.org/10.1016/j.jpsychires.2017.12.012

\begin{abstract}
АНОТАЦІЯ
Мета дослідження. Виявити мовні маркери психологічного стресу медичних працівників та визначити зміст їхніх когніцій та емоцій. Для поточного дослідження було срормульовано такі дослідницькі питання: (1) Чи є тривога, депресія та відновлюваність фракторами ризику та захисними фракторами психологічного стресу у медичних працівників, які працюють з пацієнтами з COVID-19? (2) Чи існують мовні маркери емоційного дистресу у медичних працівників, які працюють з пацієнтами з COVID-19? (3) Які ключові когніції, емоції та моделі поведінки виражені в мовленні медичних працівників? (4) Які слова-асоціації в Українському асоціативному словнику відповідають мовним маркерам професійної етики медичного персоналу?
\end{abstract}

Матеріали та методи. У дослідженні застосовується Шкала депресії Бека (BDI-II), Шкала тривожності Бека (BAI), Міні-шкала резилієнтності (BRCS), Шкала психологічного стресу (PSM-25), а також комп'ютерна програма Linguistic Inquiry and Word Count (LIWC 2015).

Результати. Результати засвідчили, що медичний персонал демонструє низький рівень психологічного стресу, депресії та тривоги та середній рівень відновлюваності. Результати множинної лінійної регресії вказують на те, що єдиним значущим негативним предиктором стресу $\epsilon$ відновлюваність. 
Когніції, емоції та мовлення медпрацівників у стресових...

Психолінгвістичний аналіз наративів медичних працівників про їхній професійний досвід лікування осіб із COVID-19 виявив ключові змістовні категорії, а саме соціальні контакти, пізнавальні процеси та час. Соціальні контакти представлені здебільшого категорією "сім'я". Слова-асоціації з Українського асоціативного словника вказують на те, що почуття провини, пов'язане з професійною етикою у медпрацівників, більш виражене у чоловіків, порівняно з жінками.

Висновки. Нові дані, отримані впродовж цього дослідження, можуть допомогти розробити ефективні заходи для медичного персоналу під час пандемії, зосереджуючись, пери за все, на чинниках захисту, та послабленні почуття провини, щоб запобігти моральній травмі у чієї професійної групи. Дослідження також порушує деякі питання комплексного підходу клінічної психолінгвістики до вивчення емоційного дистресу. Такий підхід став би плідним напрямом для подальшої роботи.

Ключові слова: клінічна психолінгвістика, мовні маркери, слова-асоціації, психологічний стрес, етика, депресія, тривожність, відновлюваність, медичні працівники, LIWC.

Засекина Лариса, Пастрик Татьяна, Козигора Мария, Федотова Татьяна \& Засекин Сергей. Когниции, эмоции и речь медработников в стрессовых ситуациях: клинические и этические имликации для исследовательских мemodos

\section{АННОТАЦИЯ}

Цель исследования. Установить языковые маркеры психологического стресса медицинских работников и определить содержание их когниций и эмоций. Для текущего исследования были сформулированы следующие исследовательские вопросы: (1). Являются ли тревога, депрессия и восстанавливаемость факторами риска и защитными факторами психологического стресса у медицинских работников, работающих с пациентами с COVID-19? (2). Существуют ли языковые маркеры эмоционального дистресса у медицинских работников, работающих с пациентами с COVID-19? (3). Какие ключевые когниции, эмоции и модели поведения выражены в речи медицинских работников? (4). Какие слова-ассоциации в Украинском ассоциативном словаре соответствуют языковым маркерам профессиональной этики медицинского персонала?

Материалы и методы. В исследовании применяется Шкала депрессии Бека (BDI-II), Шкала тревожности Бека (BAI), Мини-шкала резилиентности (BRCS), Шкала психологчческого стресса (PSM-25), а также компьютерная программа Linguistic Inquiry and Word Count (LIWC 2015).

Результаты. Результаты показали, что медицинский персонал демонстрирует низкий уровень психологического стресса, депрессии и тревоги и средний уровень восстанавливаемости. Результаты множественной линейной 
Cognition, Emotions, and Language in Front-Line Healthcare...

регрессии указывают на то, что единственным значимым негативным предиктором стресса является восстанавливаемость. Психолингвистический анализ нарративов медицинских работников об их профессионального опыта лечения лиц с COVID-19 обнаружил ключевые содержательные категории, $a$ именно социальные контакты, познавательные процессы и время. Социальные контакты представлены, в основном, категорией "семья". Слова-ассоциации из Украинского ассоциативного словаря указывают на то, что чувство вины, связанное с профрессиональной этикой у медработников, более выражено у мужчин, по сравнению с женщинами.

Выводы. Новые данные, полученные в ходе этого исследования, могут помочь разработать эфрфективные меры для медичинского персонала во время пандемии, сосредотачиваясь, прежде всего, на фракторах защиты, и ослаблении чувства вины, чтобы предотвратить моральную травму в этой профессиональной группы. Исследование также нарушает некоторые вопросы комплексного подхода клинической психолингвистики к изучению эмоционального дистресса. Такой подход стал бы плодотворным направлением для дальнейшей работы.

Ключевые слова: клиническая психолингвистика, языковые маркеры, словаассоциации, психологический стресс, этика, депрессия, тревожность, восстанавливаемость, медицинские работники, LIWC. 